\title{
Emigration Patterns and Determinants of Children of Immigrants in Switzerland
}

Illka Steiner*

* Institute of Demography and Socio-economics (I-DESO), University of Geneva, CH-1211 Geneva, ilka.steiner@unige.ch.

\section{Abstracts}

\section{Emigration Patterns and Determinants of Children of Immigrants in Switzerland}

Existing studies on emigration either focus on the first generation or the total migrant population. Analysing the Swiss context, this article explores the emigration patterns and determinants of children of immigrants in comparison with other subpopulations. We use original longitudinal data (obtained by linking the Structural Survey and the Population and Household Statistics) that provide information on emigration flows as well as on the migratory background. Results differ significantly according to the migratory status considered.

Keywords: Children of immigrants, emigration, Switzerland, longitudinal data, migratory status

\section{Emigrationsmuster und -faktoren der Immigrantenkinder in der Schweiz}

Der Fokus bestehender Emigrationsstudien ist entweder auf die erste Generation oder die Gesamtmigrationsbevölkerung gerichtet. Dieser Artikel untersucht die Emigrationsmuster und -faktoren der Immigrantenkinder im Vergleich mit anderen Bevölkerungsgruppen im Schweizer Kontext. Dafür kommen neue Längsschnittdaten zur Anwendung (die Strukturerhebung und die Statistik der Bevölkerung und der Haushalte), welche die Auswanderungen beinhalten und Aufschluss über den Migrationsstatus geben. Die Studienergebnisse variieren deutlich zwischen den einzelnen Migrationsstatus.

Schlüsselwörter: Immigrantenkinder, Auswanderung, Schweiz, Längsschnittdaten, Migrationsstatus

\section{Tendances et facteurs d'émigration des enfants d'immigrants en Suisse}

Les études existantes sur l'émigration mettent soitl'accent sur la première génération soit sur l'ensemble de la population migrante. Cet article explore les facteurs d'émigration des enfants d'immigrants en comparaison avec d'autres sous-populations dans le contexte suisse. Nous utilisons des données longitudinales (obtenues en appariant le relevé structurel et la statistique de la population et des ménages) qui décrivent les émigrations ainsi que la trajectoire migratoire. Les résultats diffèrent considérablement selon le statut migratoire considéré.

Mots-clés: Enfant d'immigrants, émigration, Suisse, données longitudinales, statut migratoire 


\title{
Emigration Patterns and Determinants of Children of Immigrants in Switzerland ${ }^{1}$
}

\author{
Ilka Steiner*
}

\section{Introduction}

Most of the scientific literature on international mobility is concerned with the arrivals in a country and its consequences in terms of integration. Studies on emigration are rare. This is obviously due to the direction of recent flows; industrialized countries are today characterized by positive net migration and national statistical systems reflect the governments' priorities. They therefore focus on the acquisition of citizenship and the structural integration of foreigners rather than on emigrants. Today, the political will to develop adequate instruments to measure emigration fails as well as their scientific analysis is lacking. Only once the phenomenon hinders economic development or poses a demographic challenge, the governments begin to address the issue. Emigration is also less covered because its measurement is more difficult: there can be delays or omissions in the registration, especially when incentives to announce such departures are lacking. Few states dispose of recording systems, such as the extensive border survey conducted in the United Kingdom. Therefore, the migratory paths of a relatively high proportion of migrants are under-registered.

The phenomenon of emigration is however not marginal in industrialized countries, and especially not in Europe. Since the end of the $19^{\text {th }}$ century, Europe was characterized by frequent departures towards North America and Latin-American countries. This flow decreased after the Second World War, but recently, the European integration has led to more temporary and circular forms of migration (Braun and Arsene 2009). In the case of Switzerland, in 2012, more than 100000 residents left the country. This group is rather diverse, since it includes Swiss citizens emigrating for various reasons, as well as foreign citizens returning to their countries of origin, or moving to third countries as part of a circulatory migration.

Due to sample size constraints, quantitative studies on emigration often either focus on the first generation or the total migrant population. Very little is known regarding the children of immigrants' propensity to be internationally mobile. Are

\footnotetext{
* Institute of Demography and Socio-economics (I-DESO), University of Geneva, CH-1211 Geneva, ilka.steiner@unige.ch.

1 This study has been realized within the research project «Impact social et économique de l'émigration depuis la Suisse», which has been funded by the Swiss National Science Foundation (SNF) (no 100017_152566).
} 
their educational qualifications or their labour market status determinant? Does the nationality matter? Focusing on the Swiss context, the aim of this article is to explore the emigration patterns and determinants of and among children of immigrants.

We use newly created longitudinal data (the Structural Survey and the Population and Household Statistics) that we linked in cooperation with the Swiss Federal Statistical Office. The data provide the residential and migratory trajectories of residents living in Switzerland during the years 2010 to 2012 as well as socio-demographic and specific migration information, such as the nationality and duration of residence. Socio-economic characteristics are available for a subsample of the population.

The paper first reviews the literature regarding the general determinants of emigration, before focussing on the emigration of children of immigrants. Second, it presents the data, definitions and methods used in this research. Third, it maps the children of immigrants' emigration patterns in comparison to that of first generation migrants and Swiss-born Swiss citizens. Using logistic regression models, we then measure the probability to emigrate according to different factors, comparing the children of immigrants to the first generation of migrants. The conclusion puts the results into perspective and indicates further avenues for research.

\section{Literature review}

\subsection{Factors of emigration}

Emigration is a global phenomenon, involving both native and foreign nationals who either grew up in the country or settled down during their life course. It affects all ages, and is due to many varied reasons, acting in variable manners and depending on the economic and political context.

Among the main factors of emigration, the literature identifies job opportunities (Prognos AG 2008) and student migration, family reasons, retirement (King et al. 2002; Huber 2003), lifestyle preferences and return migration (Wahl 2004). Depending on various demographic and socioeconomic individual features (Sriskandarajah and Drew 2006), these factors are closely linked to the life course (François-Poncet 1999) and the age of potential migrants (Rogers and Castro 1981). The factors of emigration also vary according to gender, namely regarding labour migration, where women are rather more willing to follow their partner than the other way around (Vandenbrande et al. 2006).

The neoclassical economic model alone is therefore not adapted to explain emigration patterns. For individuals from highly developed countries, such as Switzerland, the cost-benefit balance of mobility, at least in economic terms, can be quite negative (Schönenberger and Efionayi-Mäder 2010). The theory of the new economy of labour migration, which also takes into account family aspects and 
networks, is better suited to explain emigration patterns and determinants (Stark 1991; Massey et al. 1993; Faist 1997; Haug 2008).

Several studies for Switzerland and Germany underline the selectivity in the emigration process: whereas marriage or having children in school decreases the likelihood to emigrate, highly educated, young and childless individuals as well as singles show a higher propensity to emigrate (for Switzerland, Pecoraro 2012; for Germany, Sauer and Ette 2007; Erlinghagen and Stegmann 2009; Engler et al. 2015). In particular, the result regarding the educational level is in line with international trends (OECD 2008). To dispose of a high human capital allows for a better access to information as well as to higher income levels (Zhao et al. 2000) and therefore to migration opportunities. Nekby (2006) observes a U-shape relation for income and emigration: the probability to emigrate is highest for people with low or high income and lowest for medium-skilled workers.

Contextual factors, such as a region's proximity to the country border (Steiner 2014) or a high degree of urbanity of a region are positively correlated with emigration (Pecoraro 2012).

Citizenship and the migratory status are two further characteristics explaining emigration. For instance, Swiss emigration rates are higher for foreign nationals than for Swiss citizens (SFSO 2015a); similarly, in the German context, German citizenship is negatively correlated with emigration (Erlinghagen and Stegmann 2009). However, among German citizens, German nationals with a migratory background are generally the most mobile (Engler et al. 2015). According to Gundel and Peters (2008) the institutional context, and therefore the access to mobility, is decisive, as citizens of countries that have signed an agreement for the free movement of persons with the host country emigrate more easily than third country nationals. In the Swiss context, Pecoraro (2012) also found that the emigration strategies vary as a function of foreign citizenship.

Generally, the emigration of foreign citizens or the foreign-born, and namely return migration, has received more attention in migration research than the emigration of natives. The migrants' embeddedness in the host country, often approximated by the length of stay or labour market integration, impacts negatively on return migration (Constant and Massey 2003; Pecoraro 2012; Pungas et al. 2012). Most of the theories on migrant integration or assimilation suggest that the longer migrants stay, the more they become integrated in host societies, the more difficult it becomes to return, and the more they are inclined to settle down (van Baalen and Müller 2008). Return migration is therefore conceptualized as a cause and/or a consequence of "integration failure"; or as de Haas and Fokkema $(2011,575)$ put it: "While 'winners' settle, 'losers' return.” Pecoraro (2012) finds in the Swiss context that unemployment of migrants increases their probability to emigrate. Borjas and Bratsberg (1996) on the other hand assume in their return migration selection model 
that the emigrants return home either because they have failed their migration or because they achieved the objectives they had set in advance.

\subsection{Emigration of children of immigrants}

While most studies on return migration focus on the first generation or the total migrant population, very little is known regarding the immigrants' children. Some studies identify lower emigration rates for the second generation than for the first generation (Pecoraro 2012; Engler et al. 2015). However, the propensity to emigrate is higher among individuals that were born abroad and immigrated at a young age compared to the native born (Pecoraro 2012).

The sociological literature often focuses on transnationalism with the families' country of origin among the adult children of immigrants, assuming a "hypothetical continuum ranging in intensity from low to high" (Bachmeier et al. 2013, 273): visiting the parents' country of origin, sending remittance, having return intentions and actually returning, or as King and Christou (2010) put it "counter-diasporic migration." However, "analyses find little evidence of widespread, intensive transnationalism in the second generation" (Bachmeier et al. 2013), as most of these adults are oriented overwhelmingly to their life in their country of birth (Kasinitz et al. 2002; Rumbaut 2002; Haller and Landolt 2005; Tamaki 2011; Fokkema et al. 2012). For example, among the Turks, Moroccans and former Yugoslavs in 15 European cities, $63.5 \%$ have no intention of ever taking up long-term residence in their parents' country of birth (Bachmeier et al. 2013, 279). Among the Turks and former Yugoslavs in Switzerland a majority excludes even spending one year in their family's country of origin (Fibbi et al. 2015). Engler et al. (2015) also suggest that only $25 \%$ of all emigrants with German citizenship and a migratory background return to their family's country of origin.

King and Kilınc (2014) identified four types of Turkish second generation returnees from Germany: university students, future spouses embarking on marriage migration, those attracted by the Turkish lifestyle, and those for whom the return represented an "escape," for example from a failed marriage in Germany. For Górny and Osipovič (2006), the return of British Poles to Poland was due to a mixture of family factors and social capital as well as to ideological and economic reasons. The importance of the economic situation and of a positive perspective in the country of destination has also been confirmed in the Caribbean case (Conway and Potter 2009). In the Swiss context, holding a tertiary degree has no significant impact on the probability to emigrate among the second generation (Pecoraro 2012). This is confirmed for the Italian second generation in Switzerland: Wessendorf (2007) finds that only a minority had white-collar jobs before their return migration. In spite of their dream of a life in Italy, the highly skilled do not perceive any professional opportunities in their family's home country and therefore abandon their plan to return. 
Based on these literature findings, we hypothesize, first, a strong positive link between the migratory status and the likelihood to emigrate. Second, we expect return migration to the family's home country to be marginal. Third, as observed for the first generation in the literature, we expect a highly selective process in terms of socio-demographic characteristics: whereas marriage or having children in school decreases the likelihood to emigrate, young and childless individuals as well as singles show a higher propensity to emigrate. Fourth, regarding the children of immigrants' socio-professional profile, we hypothesize that their educational level does not play a role, whereas unemployment increases the likelihood to emigrate.

\section{Methodology}

\subsection{Data}

The analyses of this article rely on two distinct data sets: the Population and Household Statistics (STAPTOP) and the Structural Survey (SS).

Since 2010, the Swiss Federal Statistical Office's new register based Population and Household Statistics (STATPOP) provide individual data on a yearly basis on the total resident population as well as on its migratory flows, such as emigration. It provides information not only on the demographic characteristics (gender, age, marital status, nationality, etc.), but also on the birthplace and the length of residence in Switzerland. With the introduction of the Population Register, the decennial census was replaced by an annual sample survey, the Structural Survey (SS). This sample survey covers 3\% of the total population or 200000 persons aged 15 years or over of the permanent resident population ${ }^{2}$ living in private households. Rather mobile foreign nationals holding a short-term permit $\mathrm{L}$ are therefore excluded from the survey. However, for our analysis of children of immigrants, we suppose that most individuals hold a $\mathrm{C}$ settlement permit or were naturalized and are therefore included. Contrary to the STATPOP data, the survey includes socioeconomic information, the household composition as well as more detailed migration specific characteristics, such as the mother's or father's birthplace.

The SS sampling frame is given by STATPOP, the reference day coincides with the register survey day (31 December) and both sources include the new social security number allowing the data from both these data sets to be easily linked. In 2015, a new data base for the analysis and integration of migration in Switzerland was set up together with the Swiss Federal Statistical Office (SFSO) (for the meth-

2 According to the Swiss Federal Statistics Office (SFSO 2015b), the permanent resident population is composed of 1) Swiss nationals that have their principal residence in Switzerland, 2) foreign nationals holding a permit that is valid for at least one year (B residence permit or C settlement permit), 3) foreign nationals that have spent twelve or more months in Switzerland (with shortterm $\mathrm{L}$ permit, an $\mathrm{N}$ permit for asylum seekers or provisionally admitted foreign nationals with an F permit) as well as 3) diplomats and international civil servants. 
odolgy of its creation see Steiner and Wanner 2015). The new Swiss Longitudinal Demographic Database (SLDD) allows the monitoring of the resident population in time, since their entry into the resident population, for instance by immigration or birth, until their dropout, due to death or emigration. However, the latter is not necessarily a definitive exit, since in case of re-immigration, they reintegrate into the resident population.

In order to map the phenomenon of emigration of children of immigrants in Switzerland (chapter 4.1), we solely rely on STATPOP data (emigration movements in 2011 and 2012 and 2010 and 2011 stock data). This choice is based on the exhaustivity of the data source and therefore the actual number of emigrants included in the analysis. For the regression analysis (chapter 4.2), we use the linked SS/ STATPOP data. We consider every member of the target population (see definition in chapter 3.2) that was surveyed in the 2010 or 2011 SS and check for STATPOP emigration records the following years (2011 and 2012). All the individuals that died or dropped out of the target population for other reasons are not considered. The determinants of emigration rely on the information of the SS and therefore refer to the moment of the survey, and not to the date of emigration. This decision has been taken in order to guarantee coherence between the socio-demographic and socio-professional information available.

The quality of the data is considered as good, despite some administrative errors observed, such as delays or omissions in the registration of emigration flows (Steiner and Wanner 2015). They might therefore be slightly underestimated in STATPOP, namely for short-term emigrants (e.g. students). Furthermore, we assume that some individuals, which were selected to take part in the SS and who already had a project to emigrate, did not fill out the survey. Therefore, their representativeness might not be guaranteed. Finally, the non-exhaustive character of the SS data poses some problems when it comes to studying subpopulations, such as the children of immigrants or when geographically smaller-scale analyses are carried out. Even though the results from several years can be pooled, the sample size might remain insufficient for detailed analyses.

\subsection{Definitions and representativeness of children of immigrants in the data sets}

The operational definition of the term "second generation" varies from one study to another and therefore also impacts on their results and interpretations. As King and Christou $(2008,5)$ mention "it poses challenges both as a descriptive notion and as an anatic category." The most basic definition comprises children born in the host country to two foreign-born parents. According to this definition, children brought to the host country at a young age are counted within the first generation of immigrants, although according to King and Christou $(2008,5)$, from a sociological point of view they are "practically indistinguishable from the narrow definition of second generation." However, when including them into the target population, 
Figure 1 Categories of children of immigrants, aged 18 and over, in the two data sources (in percent)

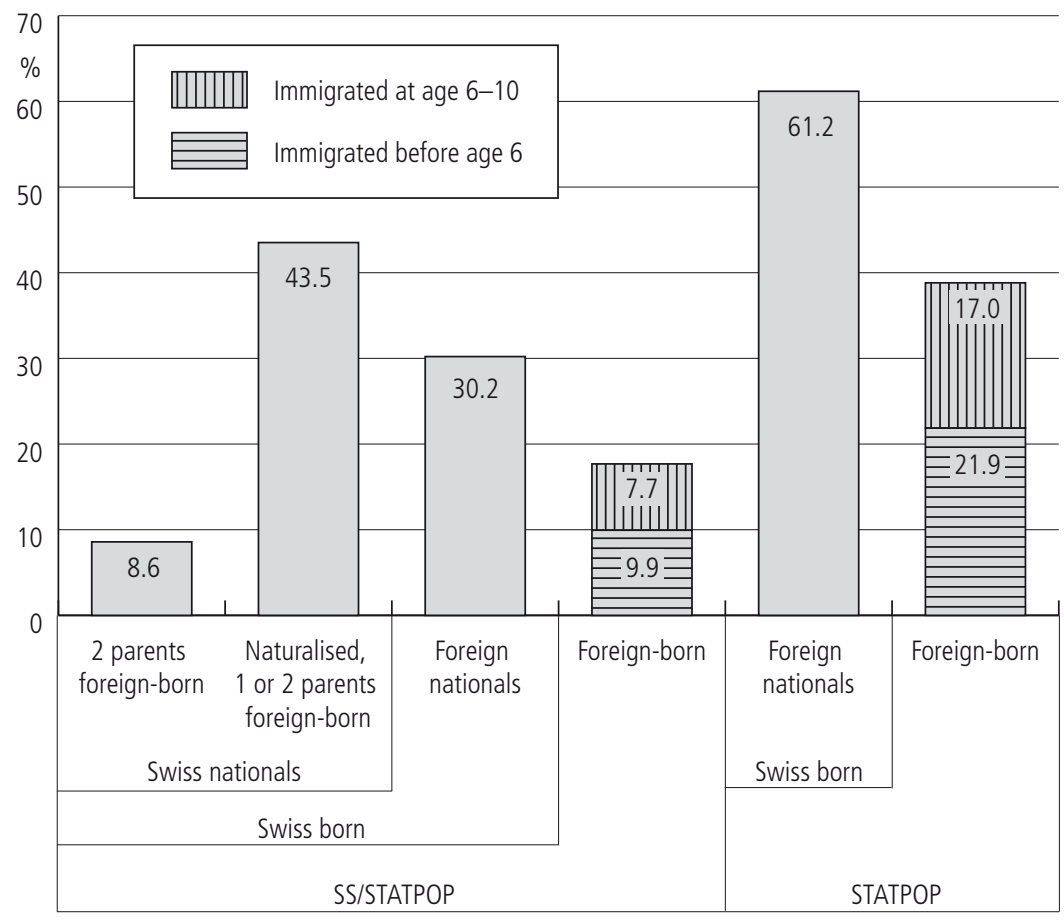

Notes: SS = Structural Survey; STATPOP = Population and Household Statistics.

Source: Linked SS/STATPOP data and STATPOP data, 2010-2012.

the question regarding the age limit arises: do we consider immigrants before the age of 12 years (Portes and Zhou 1993), 6 years (Andall 2002) or before primary school (Crul and Vermeulen 2003)?

For this article, we rely on SFSO's definition of the second generation (Kristensen 2014), which is based on recommendations from the United Nations (2006). Therefore, all persons that were born in Switzerland and 1) hold the Swiss citizenship since birth but whose two parents were born abroad, 2) were naturalized and whose one or two parents were born abroad or 3) (still) hold a foreign nationality, are considered. However, and contrary to SFSO's definition, we include children that migrated to Switzerland 4) before the age of 6 years, which corresponds to the school starting age, as well as 5) between the age of 6 and 10 years and therefore attended school before the selection process into secondary school (ISCED 2) took 
Table 1

Adult children of immigrants' stocks, number of emigrants and the probability to emigrate, according to different definitions in the two data sources

\begin{tabular}{|c|c|c|c|c|}
\hline \multirow[t]{2}{*}{ Data source } & \multirow[t]{2}{*}{$\begin{array}{l}\text { Population under } \\
\text { study }\end{array}$} & $\begin{array}{l}\text { Complete definition of } \\
\text { children of immigrants }\end{array}$ & $\begin{array}{r}\text { Swiss-born of foreign nationality } \\
\& \text { foreign-born that immigrated } \\
\text { before the age of } 10 \text { years }\end{array}$ & \multirow[t]{2}{*}{$\begin{array}{r}\text { Probability to } \\
\text { emigrate }\end{array}$} \\
\hline & & Number & Number & \\
\hline \multirow[t]{2}{*}{ SS/ STATPOP } & $\begin{array}{l}\text { Children of } \\
\text { immigrants }\end{array}$ & $\begin{array}{r}41215 \\
(441194)\end{array}$ & $\begin{array}{r}19686 \\
(227663)\end{array}$ & \multirow[t]{2}{*}{$0.45 \%$} \\
\hline & Thereof emigrants & $\begin{array}{r}313 \\
(3670)\end{array}$ & $\begin{array}{r}134 \\
(1708)\end{array}$ & \\
\hline \multirow[t]{2}{*}{ STATPOP } & $\begin{array}{l}\text { Children of } \\
\text { immigrants }\end{array}$ & & 436370 & \multirow[t]{2}{*}{$0.57 \%$} \\
\hline & Thereof emigrants & & 2485 & \\
\hline
\end{tabular}

Notes: SS = Structural Survey; STATPOP = Population and Household Statistics. Numbers in brackets are weighted data. The grey cells indicate the data used in this article. Complete definition: Swiss-born of Swiss nationality at birth (with two parents born abroad) or naturalized, Swiss born of foreign nationality, Foreign-born that immigrated before the age of 10 years.

Source: Linked SS/STATPOP data and STATPOP data, 2010-2012.

place (Graber 2011, 12-13). Finally, only adults (thus individuals 18+) are included in the analysis. We do not consider minors since we assume that they cannot yet make their own decisions about migration. Usually it is their parents that decide to migrate and the children have to follow (Figure 1).

The operationalization of the definition however greatly depends on the availability of the different variables in the data sets. Whereas the SS data contains one's father's and mother's birthplace as well information on whether someone was born with the Swiss citizenship or was naturalized, STATPOP does not register that particular information. Therefore, the aforementioned complete definition can only be applied to the SS/STATPOP data (see Figure 1). In the STATPOP data, only the subgroup of Swiss-born foreign nationals (category 3) and foreign-born children that immigrated before the age of 10 years can be identified (cat. 4 and 5).

According to the complete definition, almost 41,220 children of immigrants were surveyed in the 2010 and 2011 SS; 313 of these emigrated either in 2011 or 2012. In order to evaluate the representativeness of the sample of emigrants included in the SS, the exclusion of the first two categories allows us to compare the two data sources (see Table 1 ). Whereas the emigration rate amounts to $0.57 \%$ in STATPOP, it is smaller in the SS with $0.45 \%$. As already mentioned this bias could be due to the fact that individuals that have already planned their emigration are less disposed to complete the survey, even though it is mandatory. 


\subsection{Methods}

The STATPOP data allows computing emigration rates (chapter 4.1) for the three categories of children of immigrants - Swiss-born foreign nationals (cat. 3), and foreign-born children that immigrated before the age of 6 years (cat. 4) and between the age of 6 and 10 years (cat. 5) - as well as for the first generation of migrants and the Swiss-born Swiss citizens. The emigration rates represent the mean of two years (2011 and 2012). They are calculated by dividing the number of emigrants over one year by the population living in Switzerland at the beginning of the same year. Finally, we calculate the Pearson Correlation Coefficient between the nationality and the destination country after emigration, in order to check for return migration to the family's home country. The coefficient ranges from -1 to +1 , indicating respectively a completely negative or positive correlation. A value of 0 implies no correlation at all between the two variables.

When studying the determinants of emigration (chapter 4.2), we consider the linked SS/STATPOP data. The data allows the identification of the children of immigrants among the Swiss-born Swiss citizens (cat. 1 and 2), which account for $52 \%$ of all children of immigrants in Switzerland (see Figure 1). Therefore our comprehension of the phenomenon can be improved and discrepancies between subgroups better investigated. Moreover, the SS/STATPOP data provide a large selection of explicative variables necessary for our analysis, such as the labour market status or the household composition.

Logistic regression models are used to test the effects of the different variables on the probability to emigrate (Cox and Snell 1989). The dependent binary variable distinguishes emigrants (1) from non-emigrants (0). The models are estimated for the children of immigrants as well as for the first generation of migrants to better assess and identify the determinants of emigration.

We run three different models, where model 1 and 2 regard the children of immigrants and model 3 the first generation of immigrants. According to our hypotheses $(1,3$ and 4$)$, the migratory status is controlled by the different categories of children of immigrants in model 1, the distinction between the Swiss-born and the foreign-born children of immigrants in model 2 and the length of stay for the first generation of immigrants in model 3. Second, we distinguish the different nationalities by geographic proximity and supranational organizations, considering Swiss citizens, nationals of the neighbouring countries (Germans, Italians, and French), Spanish and Portuguese, the remaining EU/EFTA nationals, other European citizens, the remaining OECD citizens ${ }^{3}$ and those of remaining countries. According to the literature, the socio-demographic profile is approximated by age categories, gender and the household composition. The latter is categorized according to the degree of responsibility for and the dependency of other persons: living alone or

Remaining OECD citizens: Australia, Canada, Chile, USA, South Korea, Israel, Japan, Mexico and New Zealand. 
with people other than his-her own family, living with a partner and living with children. The status on the labour market (employed, unemployed, inactive) and the highest education achieved (secondary 1, secondary 2 and tertiary) control for the socio-economic profile. Finally, introducing contextual factors, we control for the proximity of the region to the border (MS spatial mobility border region or inland region) as well as the urbanity of the region.

\section{$4 \quad$ Emigration patterns and determinants}

\subsection{Mapping emigration patterns}

This chapter discusses emigration rates of individuals with different migratory statuses. The analysis is solely based on STATPOP data. The results are presented in Table 2.

The emigration rate for the first generation of migrants is seven times higher than for the children of immigrants (all categories), with $3.63 \%$ compared to $0.57 \%$. In comparison, the Swiss-born Swiss citizens ${ }^{4}$ show the smallest likelihood to leave Switzerland (3 out of 1000 , i. e. $0.32 \%$ ). We observe slight differences among the children of immigrants: Swiss-born individuals leave the country less frequently $(0.53 \%)$ than the foreign-born that arrived before the age of 6 years $(0.59 \%)$ and between the age of 6 and 10 years $(0.67 \%)$. Therefore, the foreign-born that arrived before the age of 6 years have quite similar emigration probabilities to the Swiss-born children of immigrants. These results point to a varying propensity for international mobility according to the migratory status considered, and therefore to a validation of our first hypothesis.

Regarding the children of immigrants, this first hypothesis seems to apply rather to men than to women, because the latters' likelihood of being internationally mobile is more homogenous (between $0.54 \%$ and $0.59 \%$ ) over the different categories considered than for men (varying from $0.53 \%$ to $0.73 \%$ ).

We observe three age related emigration patterns according to the migratory status (see Figure 2). First generation immigrants and the Swiss-born Swiss citizens show a steady decrease in their propensity to emigrate. Among the children of immigrants, the highest rates can be observed within the early career age category (25-34 years) and the pre-retirement age category (55-64 years). However, whereas the Swiss-born present the highest emigration rates before retirement $(0.95 \%)$, the foreign-born's peak is observed between 18 and 34 years $(0.71 \%)$. These results hold for both women and men.

4 Since STATPOP data does not contain one's father's and mother's birthplace, the category of Swiss-born Swiss citizens comprises different subpopulations: children of immigrants that were born in Switzerland and are holding the Swiss citizenship, but also Swiss citizens with no migratory background. 


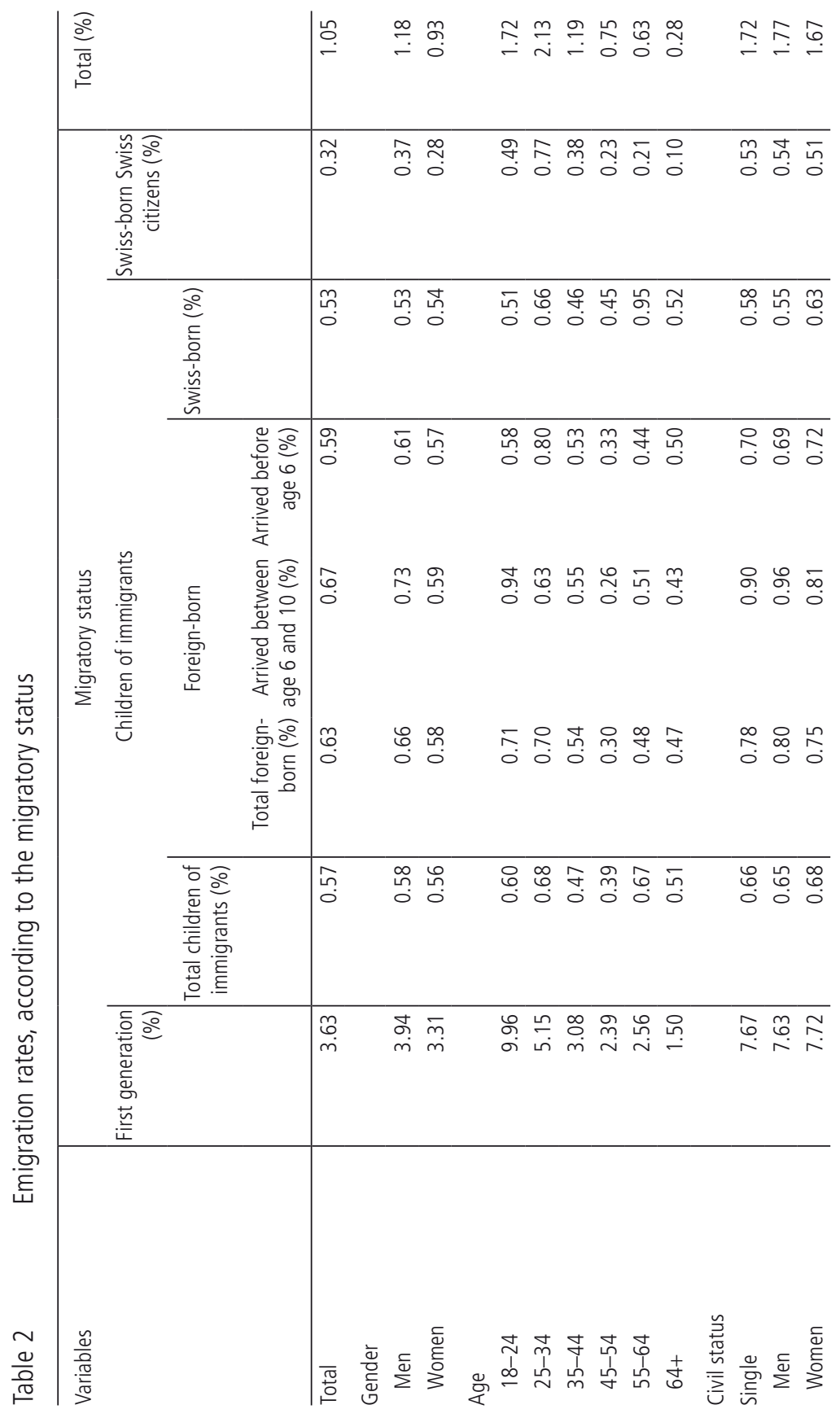




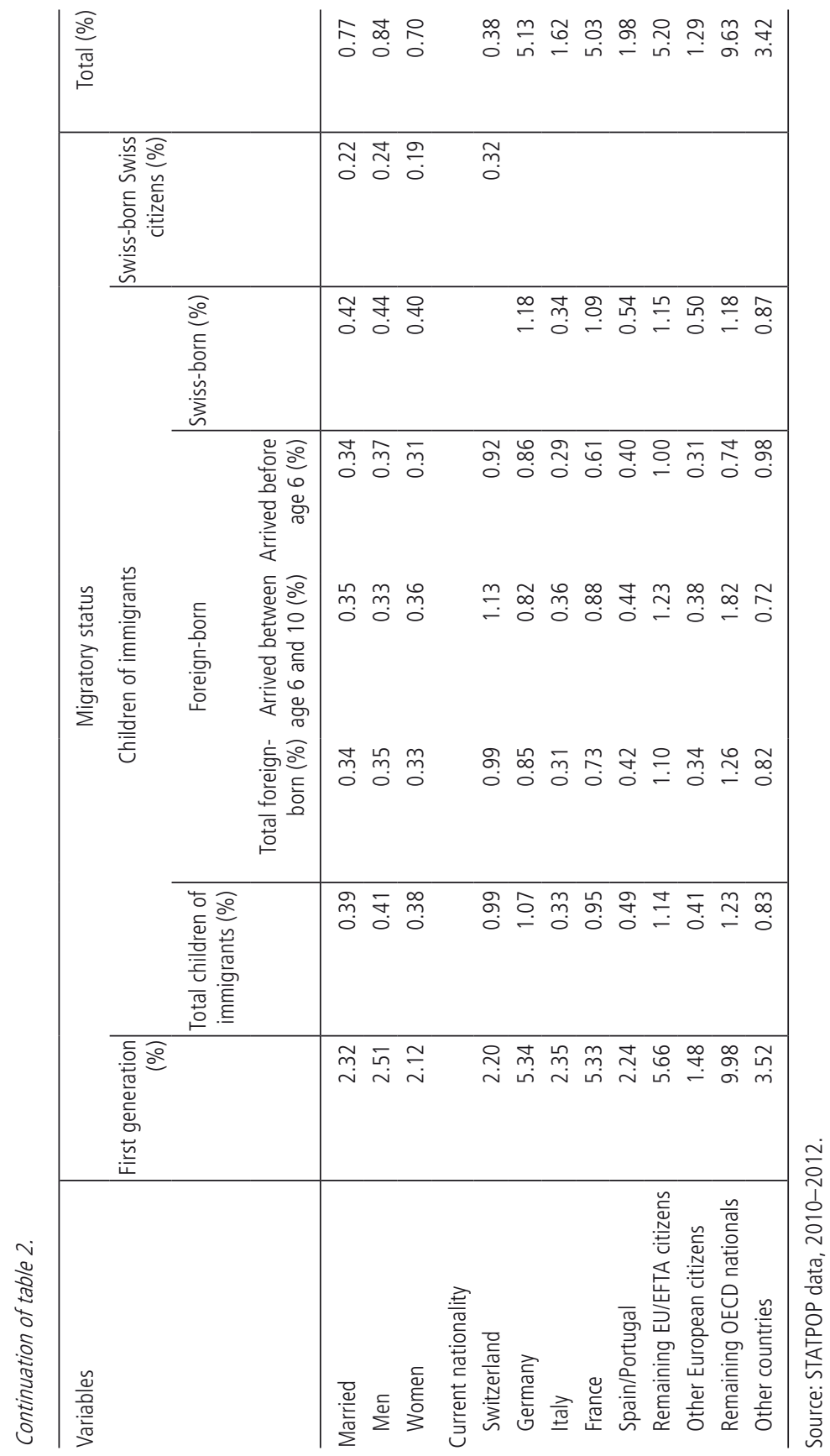


Figure 2 Age related emigration patterns, according to the migratory status, indexed evolution (Index 100 $=18-24$ years)

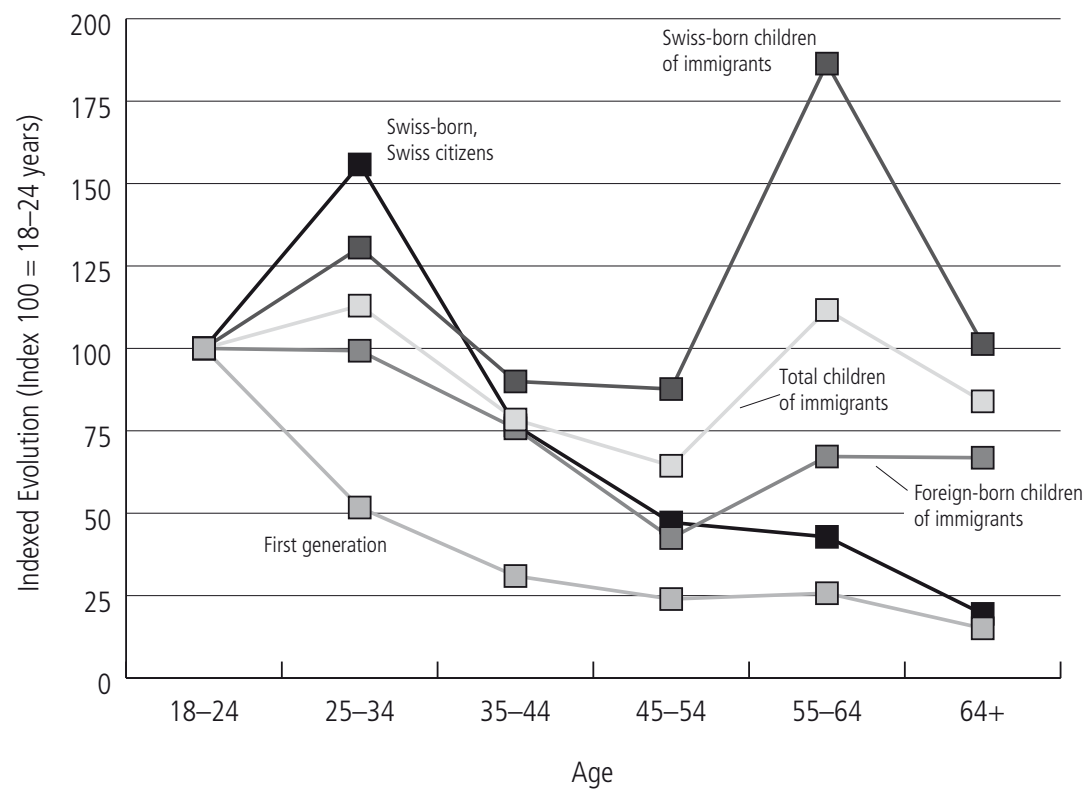

Source: STATPOP data, 2010-2012.

During early adult life (18-34 years), educational reasons and the absence of a partnership or family responsibilities can explain the increased propensity to be mobile. The emigration rates of the children of immigrants according to civil status confirm this assumption and therefore point to a validation of one part of our third hypothesis: singles emigrate more often $(0.66 \%)$ than married individuals $(0.39 \%)$. Interestingly, gender differentials are rather small between the different migratory and civil statuses. The children of immigrants' emigration rates for instance only differ by $0.03 \%$ (single: men $0.65 \%$ and women $0.68 \%$; married: men $0.41 \%$ and women $0.38 \%$ ).

Concerning the nationality, we observe the highest emigration rates among the remaining OECD nationals (9.63\%), followed by the remaining EU/EFTA citizens (5.20\%) and Germans (5.13\%). The lowest rates are observed for the other European citizens $(1.29 \%)$. These results might be explained by their differing access to mobility, due to their citizenship. Among the children of immigrants, mobility is highest for the same nationalities, even though at a much lower level (e.g. remaining OECD nationals $1.23 \%$ ). However, it is the Italians that present the lowest rates $(0.33 \%)$, followed by the other European citizens $(0.41 \%)$. Therefore, among the 
children of immigrants, the access to mobility seems to play an important role, even though not exclusively, since the Italians benefit from the free movement of persons within the European Union.

We find quite a high and significant association between the nationality and the country of destination for the first generation of migrants (Pearson Correlation Coefficients $=0.63$ ), followed by the foreign-born children of immigrants (0.44). One fifth of the latter group has a citizenship from a European country that is not part of the EU/EFTA. Therefore, once they emigrate, they most often choose their home country, since their choice of possible destination countries is restricted. Albeit at a weaker level, a positive and significant correlation can still be observed for the Swiss-born children of immigrants (0.34). Since the latter group comprises citizens from many European countries, their spectrum of possible destination countries is much larger. With regards to these results, our first hypothesis regarding the importance of the migratory status in migration behaviour seems not only to hold for emigration but also for return migration. Our third hypothesis, regarding return migration among the children of immigrants to their family's home country being marginal, cannot be confirmed. Even though it is lower than for the first generation, return migration takes place, especially within some specific nationality groups.

\subsection{Determinants of emigration}

In order to better understand the determinants of emigration, we compute logistic regression models for the children of immigrants as well as for the first generation migrants, based on the linked SS/STAPTOP data. The results are presented in Table 3.

There are no significant differences between the foreign-born and the Swissborn children of immigrants (model 2). However, whereas the Swiss-born of Swiss nationality at birth present a significantly higher probability, the Swiss-born of foreign nationality present a significantly lower probability to emigrate compared to the foreign-born that immigrated between the age of 6 and 10 years (model 1). These results might be explained by the differing access to mobility, offered by their citizenship status. Owing to their Swiss citizenship, the former always have the possibility to return to Switzerland in case their migratory project fails.

Concerning the nationality, only the Italians present a significantly lower and the French a significantly higher probability to emigrate than the Swiss. This latter result could be explained by residential mobility across the international border between the French-speaking cantons and France. In particular, the saturated housing market of Geneva could push households to relocate in the French border regions (Hauri 2009). This assumption is supported by a lower probability to emigrate of the children of immigrants residing in an inland region in comparison to those residing in a border region (model 1 and 2).

Unsurprisingly, the first generation shows a clear decrease in their probability to leave Switzerland with an increasing length of stay (model 3). Moreover, once 
Table 3 Results of the logistic regression, modelling the probability to emigrate, according to the migratory status

\begin{tabular}{|c|c|c|c|c|c|c|}
\hline \multirow[t]{3}{*}{ Variables } & \multicolumn{4}{|c|}{ Children of immigrants } & \multirow{2}{*}{\multicolumn{2}{|c|}{$\begin{array}{l}\text { First Generation } \\
\text { Model } 3\end{array}$}} \\
\hline & \multicolumn{2}{|c|}{ Model 1} & \multicolumn{2}{|c|}{ Model 2} & & \\
\hline & Odds & Sig. & Odds & Sig. & Odds & Sig. \\
\hline Categories of children of immigrants & & *** & & & & \\
\hline Swiss born & & & Ref. & & & \\
\hline Swiss born of Swiss nationality at birth & 1.758 & *** & & & & \\
\hline Swiss born naturalized & 0.993 & & & & & \\
\hline Swiss born of foreign nationality & 0.719 & ** & & & & \\
\hline Foreign born & & & 0.944 & & & \\
\hline Foreign born, immigrated before age 6 & 0.857 & & & & & \\
\hline Foreign born, immigrated between age 6 and 10 & Ref. & & & & & \\
\hline Length of stay & & & & & & *** \\
\hline Up to 2 years & & & & & Ref. & \\
\hline Between 2 and 5 years & & & & & 0.74 & *** \\
\hline Between 5 and 10 years & & & & & 0.39 & ** \\
\hline Between 10 and 20 years & & & & & 0.19 & *** \\
\hline Between 20 and 30 years & & & & & 0.17 & *** \\
\hline More than 30 years & & & & & 0.12 & *** \\
\hline Current nationality & & & & $* * *$ & & $* * *$ \\
\hline Swiss & & & Ref. & & Ref. & \\
\hline German & & & 1.519 & & 1.57 & * \\
\hline Italian & & & 0.36 & ** & 1.15 & * \\
\hline French & & & 1.653 & * & 1.32 & \\
\hline Spanish/Portuguese & & & 0.664 & & 1.41 & \\
\hline Remaining EU/EFTA citizens & & & 1.088 & & 1.78 & *** \\
\hline Other European nationals & & & 0.517 & & 0.76 & $* * *$ \\
\hline Remaining OECD citizens & & & 0.734 & & 2.7 & $* * *$ \\
\hline Other countries & & & 1.574 & & 1.38 & \\
\hline Age group & & $* * *$ & & $* * *$ & & *** \\
\hline $18-24$ & 0.86 & $* * *$ & 0.825 & $* * *$ & 1.02 & ** \\
\hline $25-34$ & Ref. & & Ref. & & Ref. & \\
\hline $35-44$ & 0.561 & * & 0.551 & * & 0.93 & ** \\
\hline $45-54$ & 0.307 & & 0.298 & & 0.67 & * \\
\hline $55-64$ & 0.207 & & 0.216 & & 0.96 & ** \\
\hline $65+$ & 0.095 & ** & 0.094 & ** & 0.34 & *** \\
\hline
\end{tabular}


Continuation of table 3.

\begin{tabular}{|c|c|c|c|c|c|c|}
\hline \multirow[t]{3}{*}{ Variables } & \multicolumn{4}{|c|}{ Children of immigrants } & \multirow{2}{*}{\multicolumn{2}{|c|}{$\begin{array}{c}\text { First Generation } \\
\text { Model } 3\end{array}$}} \\
\hline & \multicolumn{2}{|c|}{ Model 1} & \multicolumn{2}{|c|}{ Model 2} & & \\
\hline & Odds & Sig. & Odds & Sig. & Odds & Sig. \\
\hline Sex & & & & & & * \\
\hline Men & Ref. & & Ref. & & Ref. & \\
\hline Women & 0.941 & & 0.909 & & 0.91 & * \\
\hline Household composition & & ** & & ** & & *** \\
\hline $\begin{array}{l}\text { Living alone or with other people, without } \\
\text { children }\end{array}$ & Ref. & & Ref. & & Ref. & \\
\hline Living with a partner, without children & 1.085 & & 1.116 & & 0.55 & $* * *$ \\
\hline Living with children & 0.628 & *** & 0.642 & $* * *$ & 0.56 & $* * *$ \\
\hline Work status & & $* * *$ & & $* * *$ & & *** \\
\hline Employed & 0.353 & ** & 0.353 & $* *$ & Ref. & \\
\hline Unemployed & Ref. & & Ref. & & 1.51 & \\
\hline Inactive & 0.729 & & 0.714 & & 2.02 & $* * *$ \\
\hline Highest education & & ** & & ** & & $* * *$ \\
\hline Secondary 1 & 0.55 & & 0.6 & & 0.52 & $* * *$ \\
\hline Secondary 2 & 0.582 & & 0.624 & & 0.64 & \\
\hline Tertiary & Ref. & & Ref. & & Ref. & \\
\hline Situation of region & & ** & & ** & & \\
\hline Border region & Ref. & & Ref. & & Ref. & \\
\hline Inland region & 0.684 & ** & 0.678 & ** & 0.97 & \\
\hline Type of region & & & & & & * \\
\hline Urban & Ref. & & Ref. & & Ref. & \\
\hline Rural & 0.903 & & 0.89 & & 0.85 & * \\
\hline N & 41215 & & 41215 & & 60739 & \\
\hline Emigrants & 313 & & 313 & & 2082 & \\
\hline
\end{tabular}

${ }^{* * *} p \leq 0.001,{ }^{* *} p \leq 0.01,{ }^{*} p \leq 0.05$.

Source: Linked SS/STATPOP data, 2010-2012.

controlled for all factors, all nationalities of the first generation, except for citizens from the other European countries, show a higher propensity to emigrate than the Swiss nationals. Among the latter, we find a high proportion of naturalized foreigners (95\%). This result supports the assumption that the wish to re-settle in another country is lowered because of the costly and lengthy naturalization process and therefore a stronger link with the destination country.

As already discussed in the previous chapter, the overall propensity to emigrate decreases with age, except for early career adults (25-34 years) among the children 
of immigrants. Contrary to what the descriptive analysis implied, the result for the children of immigrants aged 55 to 64 years is not significant. However, this is most likely due to the low sample size. The odds for pre-retirement migrants of the first generation slightly increase compared to individuals aged 45 to 54 years old. Further, inactive individuals show the highest propensity to emigrate, which could be due to the fact that this group is composed of $70 \%$ of retirees. These results support the assumption of an important return migration or at least emigration of the first generation approaching retirement.

Confirming the descriptive results and contrary to the tendency for the first generation, we do not find any significant effects for gender among the children of immigrants. The results regarding the household composition confirm one part of our third hypothesis that family responsibilities hinder emigration.

Regarding socio-professional characteristics, the analysis confirms our fourth hypothesis. First, unemployed children of immigrants (but also the first generation) show a significantly higher likelihood to emigrate than the employed. Second, the differences between the educational levels are not significant for the children of immigrants, even though the odds rather point to an increased probability to emigrate for individuals holding a tertiary degree.

\section{Conclusion}

The aim of this article was to explore the emigration patterns and determinants of and among children of immigrants in Switzerland compared to other population groups. In 2010 and 2011, an average of only 6 out of 1000 children of immigrants left Switzerland. In comparison, the first generation accounted for 36 emigrants (out of 1000 persons). Therefore, the emigration of children of immigrants in Switzerland presents today a rather marginal phenomenon.

When considering the different generations of migrants, we observe a strong link between the migratory status and the propensity for international mobility: The emigration rates decrease between the first generation, the children of immigrants and the Swiss-born Swiss citizens. However, rather small differences were detected among the children of immigrants. As for the first generation, their access to mobility, depending on their citizenship status, seems to play an important role for some specific nationality groups.

The latter result also holds for return migration. Even though it is lower than for the first generation, return migration takes place, especially among some specific nationality groups, such as citizens of European countries that are not part of the EU/EFTA, because their spectrum of possible destination countries is restricted, due to their citizenship status. 
In accordance with the literature, the life course and the age of the children of immigrants are two critical factors that influence the timing and the determinants of emigration: being young or not having children increased their likelihood to emigrate. Finally, our hypothesis that unemployment increases their probability to emigrate, and that their educational level does not play a role in emigration, was confirmed.

Some particular aspects, such as a more detailed analysis of return migration of specific nationalities, could not be further undertaken due to the low sample size. For the same reason, the regression models only provide an exploratory analysis and preliminary indications concerning the emigration of children of immigrants. In the future, the further development of the Swiss Longitudinal Demographic Database will make it possible, with the pooling of data over several years, to include a larger sample in the analyses, and hence to move beyond the present data constraints.

\section{$6 \quad$ References}

Andall, Jacqueline. 2002. Second-Generation Attitude? African-Italians in Milan. Journal of Ethnic and Migration Studies 28(3): 389-407.

Bachmeier, James D., Laurence Lessards-Phillips, and Tineke Fokkema. 2013. The Gendered Dynamics of Integration and Transnational Engagement among Second-Generation Adults in Europe. Pp. 268-293 in The International Handbook on Gender, Migration and Transnationalism, edited by Laura Osa and Natalia Ribas-Mateos. Cheltenham: Eward Elgar Publishing Limited.

Borjas, George J., and Bernt Bratsberg. 1996. Who Leaves? The Outmigration of the Foreign-Born. Review of Economics and Statistics 78(1): 165-176.

Braun, Michael, and Camelia Arsene. 2009. The Demographics of Movers and Stayers in the European Union. Pp. 26-51 in Pioneers of European Integration. Citizenship and Mobility in the EU, edited by Ettore Recchi and Adrian Favell. Cheltenham: Edward Elgar Publishing Limited.

Constant, Amelie, and Douglas S. Massey. 2003. Self-Selection, Earnings, and Out-Migration: A Longitudinal Study of Immigrants to Germany. Journal of Population Economics 16(4): 631-653.

Conway, Dennis, and Robert Potter. 2009. Return of the Next Generation: Transnational Mobilites, Family Demographics and Experiences, Multi-local Spaces. Pp. 223-242 in Return Migration of the Next Generations: $21^{\text {st }}$ Century Transnational Mobility, edited by Dennis Conway and Robert Potter. Farnham: Ashgate Publishing, Ltd.

Cox, David Roxbee, and E. Joyce Snell. 1989. Analysis of Binary Data. London: CRC Press.

Crul, Maurice, and Hans Vermeulen. 2003. The Second Generation in Europe. International Migration Review 37(4): 965-986.

de Haas, Hein, and Tineke Fokkema. 2011. The Effects of Integration and Transnational Migration Intentions. Demographic Research 25: 755-782.

Engler, Marcus, Marcel Erlinghagen, Andreas Ette, Lenore Sauer, Friedrich Scheller, Jan Schneider, and Caroline Schultz. 2015. International Mobil. Motive, Rahmenbedingungen und Folgen der Aus- und Rückwanderung deutscher Staatsbürger. Berlin und Wiesbaden: Forschungsbereich beim Sachverständigenrat deutscher Stiftungen für Integration und Migration (SVR), Bundesinstitut für Bevölkerungsforschung (BiB), Lehrstuhl für Empirische Sozialforschung an der Universität Duisburg-Essen. 
Erlinghagen, Marcel, and Tim Stegmann. 2009. Goodbye Germany - und dann? Erste Ergebnisse einer Pilotstudie zur Befragung von Auswanderern aus Deutschland. SOEPpapers on Multidisciplinary Panel Data Research 193. DIW, Berlin.

Faist, Thomas. 1997. The Crucial Meso-Level. Pp. 187-217 in International Migration, Immobility and Development, edited by Tomas Hammar, Grete Brochmann, Kristof Tamas, and Thomas Faist. Oxford: Berg.

Fibbi, Rosita, Ceren Topgül, Dusan Ugrina, and Philippe Wanner. 2015. The New Second Generation: Youth of Turkish and Former Yugoslav Descent in Zurich and Basel. Amsterdam: Amsterdam University Press.

Fokkema, Tineke, Laurence Lessard-Phillips, James Bachmeier, and Susan Brown. 2012. The Link between the Transnational Behaviour and Integration of the Second Generation in European and American Cities. Nordic Journal of Migration Research 2(2): 111-123.

François-Poncet, Jean. 1999. La fuite des cerveaux, mythe ou réalité ? Rapport du Sénat français 388. Paris: Sénat.

Górny, Agata, and Dorota Osipovič. 2006. Return Migration of Second-Generation British Poles. CMR Working Papers 6(64).

Graber, Matthias. 2011. Schülerinnen, Schüler und Studierende 2009/10. Neuchâtel: SFSO.

Gundel, Sebastian, and Heiko Peters. 2008. What Determines the Duration of Stay of Immigrants in Germany? Evidence from a Longitudinal Duration Analysis. International Journal of Social Economics 35(11): 769-782.

Haller, William, and Patricia Landolt. 2005. The Transnational Dimensions of Identity Formation: Adult Children of Immigrants in Miami. Ethnic and Racial Studies 28(6): 1182-1214.

Haug, Sonja. 2008. Migration Networks and Migration Decision-Making. Journal of Ethnic and Migration Studies 34(4): 585-605.

Hauri, Ernst. 2009. Mehr ausländische Konkurrenz: Beobachtung des Wohnungsmarkts. Terra cognita 14: 78-81.

Huber, Andreas. 2003. Sog des Südens. Zurich: Seismo.

Kasinitz, Philip, Mary C. Waters, John H. Mollenkopf, and Merih Anil. 2002. Transnationalism and the Children of Immigrants in Contemporary New York. Pp. 96-122 in The Changing Face of Home: The Transnational Lives of the Second Generation, edited by Peggy Levitt and Mary C. Waters. New York: Russell Sage Foundation Press.

King, Russell, and Anastasia Christou. 2008. Cultural Geographies of Counter-Diasporic Migration: The Second Generation Returns "Home." Sussex Migration Working Paper 45. University of Sussex, Brighton.

King, Russell, and Anastasia Christou. 2010. Cultural Geographies of Counter-Diasporic Migration: Perspectives from the Study of Second-Generation "Returnees" to Greece. Population, Space and Place 16: 103-119.

King, Russell, and Nilay Kilınc. 2014. Routes to Roots: Second-Generation Turks from Germany "Return" to Turkey. Nordic Journal of Migration Research 4(3): 126-133.

King, Russell, Tony Warnes, and Allan Williams. 2002. Sunset Lives: British Retirement Migration to the Mediterranean. Oxford: Berg.

Kristensen, Ewa. 2014. Methodenbericht zum Indikatorensystem der Integration der Bevölkerung mit Migrationshintergrund. Konzepte, Methoden, Auswahlverfahren und Quellen. Neuchâtel: SFSO.

Massey, Douglas S., Joaquin Arango, Graeme Hugo, Ali Kouaouci, Adela Pellegrino, and J. Edward Taylor. 1993. Theories of International Migration: A Review and Appraisal. Population and Development Review 19(3): 431-466.

Nekby, Lena. 2006. The Emigration of Immigrants, Return vs. Onward Migration: Evidence from Sweden. Journal of Population Economics 19(2): 197-226.

OECD. 2008. The Global Competition for Talent: Mobility of the Higly Skilled. Paris: OECD. 
Pecoraro, Marco. 2012. Rester ou partir: Les déterminants de l'émigration hors de Suisse. Pp. 141-155 in La démographie des étrangers en Suisse, edited by Philippe Wanner. Zurich: Seismo.

Portes, Alejandro, and Min Zhou. 1993. The New Second Generation: Segmented Assimilation and its Variants. The Annals of the American Academy of Political and Social Science 530(1): 74-96.

Prognos AG. 2008. Gründe für die Auswanderung von Fach- und Führungskräften aus Wirtschaft und Wissenschaft. Studie im Auftrag des Bundesministeriums für Wirtschaft und Technologie. Basel and Berlin: Prognos AG.

Pungas, Enel, Ott Toomet, Tiit Tammaru, and Kristi Anniste. 2012. Are Better Educated Migrants Returning? Evidence from Multi-Dimensional Education Data. Norface Migration Discussion Paper 2012-18.

Rogers, Andrei, and Luis J. Castro. 1981. Age Patterns of Migration: Cause-Specific Profiles. Research Reports RR-81-6: 125-159.

Rumbaut, Rubén G. 2002. Severed or Sustained Attachments? Language, Identity, and Imagined Communities in the Post-Immigrant Generation. Pp. 43-95 In The Changing Face of Home: The Transnational Lives of the Second Generation, edited by Peggy Levitt and Mary C. Waters. New York: Russell Sage Foundation Press.

Sauer, Lenore, and Andreas Ette. 2007. Auswanderung aus Deutschland, Stand der Forschung und erste Ergebnisse zur internationalen Migration deutscher Staatsbürger. Wiesbaden: Bundesinstitut für Bevölkerungsforschung.

Schönenberger, Silvia, and Denise Efionayi-Mäder. 2010. Die Fünfte Schweiz: Auswanderung und Auslandschweizergemeinschaft. Neuchâtel: Schweizerisches Forum für Migrations- und Bevölkerungsstudien (SFM).

Sriskandarajah, Dhananjayan, and Catherine Drew. 2006. Brits Abroad. Mapping the Scale and Nature of British Emigration. London: IPPR.

Stark, Oded. 1991. The Migration of Labour. Cambridge: Basel Blackwell.

Steiner, Ilka. 2014. Spatial Selectivity and Demographic Impact of Recent German Immigrants in Swiss Regions. Europa Regional 19.2011 (2014) 2: 56-68.

Steiner, Ilka, and Philippe Wanner. 2015. Towards a New Data Set for the Analysis of Migration and Integration in Switzerland. NCCR On the Move Working Paper 1.

SFSO (Swiss Federal Statistical Office). 2015a. Components of Population Change - Data, indicators. Migrations. Neuchâtel: SFSO, http://www.bfs.admin.ch/bfs/portal/en/index/themen/01/06/ blank/key/08.html (16.11.2015).

SFSO (Swiss Federal Statistical Office). 2015b. Topics, Population, Statistical Sources and Concepts, Definitions. Neuchâtel: SFSO, http://www.bfs.admin.ch/bfs/portal/en/index/themen/01/11/ def.html (16.11.2015).

Tamaki, Emi. 2011. Transnational Home Engagement among Latino and Asian Americans: Resources and Motivation. International Migration Review 45(1): 148-173.

United Nations. 2006. Conference of European Statisticians Recommendations for the 2010 Census of Population and Housing. New York and Geneva: United Nations Economic Commission for Europe.

van Baalen, Brigitte, and Tobias Müller. 2008. Return Intentions of Temporary Migrants: the Case of Germany. Paper presented at the Second Conference of Transnationality of Migrants. Louvainla-Neuve, Belgium, January 22-24, 2009.

Vandenbrande, Tom, Laura Coppin, Peter van der Halle, Peter Ester, Didier Fourage, Anette Fasang, Sara Geerdes, and Klaus Schömann. 2006. Mobility in Europe. Analysis of the 2005 Eurobarometer Survey on Geographical and Labour Market Mobility. Dublin: European Foundation for the Improvement of Living and Working Conditions.

Wahl, Stefanie. 2004. Deutschland-ein Auswanderungsland. IWG-Impulse 2004. 
Wessendorf, Susanne. 2007. "Roots Migrants": Transnationalism and "Return" among Second-Generation Italians in Switzerland. Journal of Ethnic and Migration Studies 33(7): 1083-1102.

Zhao, John, Doug Drew, and T. Scott Murray. 2000. Brain Drain and Brain Gain: The Migration of Knowledge Workers from and to Canada. Education Quarterly Review 6(3): 8-35. 


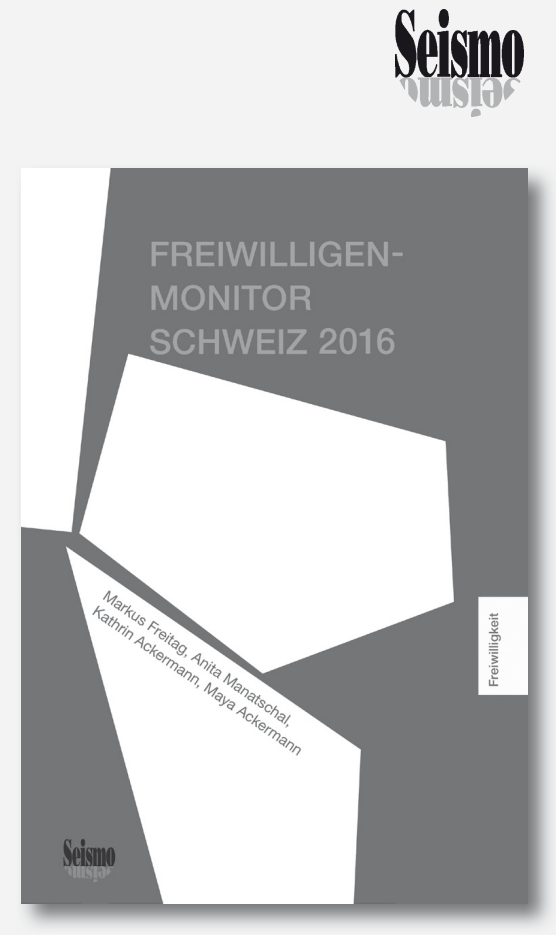

Rund ein Viertel der Personen über 15 Jahren engagiert sich in der Schweiz unentgeltlich in einer Organisation, zehn Prozent besetzen ein gewähltes Ehrenamt. Und fast 40 Prozent wirken als Freiwillige ausserhalb von Vereinen. Insgesamt leisten die Menschen in der Schweiz etwa 700 Millionen Stunden Freiwilligenarbeit pro Jahr. Dies entspricht etwa neun Prozent der geleisteten 7700 Millionen Stunden Erwerbsarbeit. Die Bewohnerinnen und Bewohner der Schweiz sind aber je nach Geschlecht, Alter, Region, Grösse des Wohnorts, Religionszugehörigkeit, Bildungsniveau, Einkommen, Zivilstand und beruflicher Stellung unterschiedlich stark freiwillig engagiert.

Nach 2007 und 2010 wurde das freiwillige Engagement in der Schweiz mit diesem Monitor zum dritten Mal erforscht. Neben AnaIysen zum Verlauf und zu den Beweggründen wie möglichen Anreizen unbezahlter www.seismoverlag.ch/info@seismoverlag.ch www.editions-seismo.ch/info@editions-seismo.ch

Markus Freitag, Anita Manatschal, Kathrin Ackermann und Maya Ackermann (Hrsg.)

\section{Freiwilligen-Monitor Schweiz 2016}

\author{
Reihe «Freiwilligkeit»
}

288 Seiten, ISBN 978-3-03777-166-2, SFr. 38.-

Arbeit liefert die Studie auch erstmalig Informationen zum freiwilligen Engagement im Internet und untersucht spezifisch die Situation junger Erwachsener und Menschen mit Migrationshintergrund. Zudem werden Einsichten zum Persönlichkeitsprofil von Freiwilligen und deren politischen und sozialen Einstellungen präsentiert.

Markus Freitag ist Direktor und Ordinarius am Institut für Politikwissenschaft der Universität Bern und Inhaber des dortigen Lehrstuhls für Politische Soziologie.

Anita Manatschal ist Postdoktorandin an der University of California, Berkeley.

Kathrin Ackermann und Maya Ackermann sind Doktorandinnen und wissenschaftliche Mitarbeiterinnen am Institut für Politikwissenschaft der Universität Bern. 